\title{
International orthopaedics today
}

\author{
Marko Pećina
}

Published online: 17 December 2014

(C) SICOT aisbl 2014

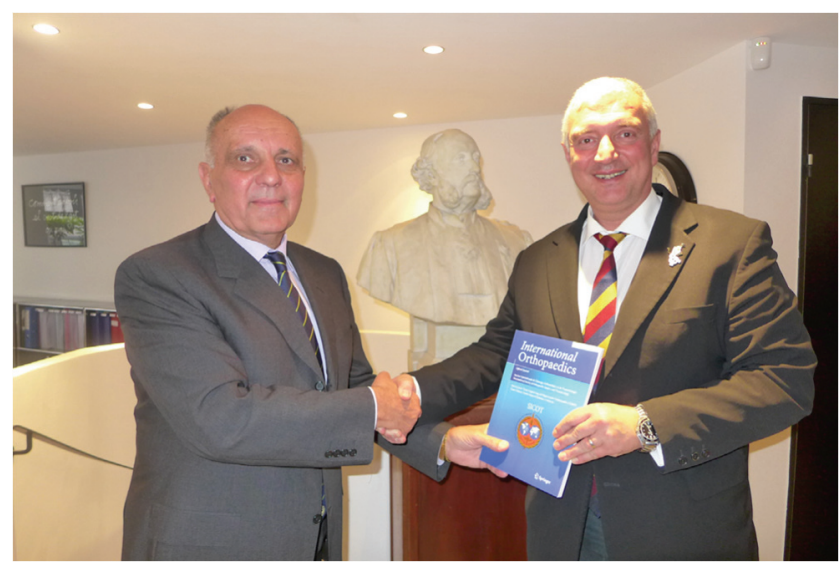

Marko Pećina and Marius M. Scarlat

Where I left off, you'll hang on;

where I failed, you will not.

At the end of my mandate as Editor-in-Chief of International Orthopaedics (2009-2014) I would like to present a short current status of our journal.

The IMPACT FACTOR for 2009 was $\mathbf{1 . 8 2 5}$; for the year 2010, 1.561; for the year 2011, 2.025; for year 2012 it was 2.319 and for 2013 the IMPACT FACTOR is $\mathbf{2 . 0 1 9}$ !

I hope that we will be able to improve this Impact Factor of our journal - 2.019 and that we will have received sufficient good or high quality articles during 2014. Last year (2013) we received more than 2200 articles and in 2014 there were more than 2400 articles. Actually we have a backlog of articles accepted for publication in our journal which could fill three

M. Pećina $(\bowtie)$

Department of Orthopaedic Surgery, University of Zagreb School of

Medicine, Zagreb, Croatia

e-mail: marko.pecina@zg.t-com.hr issues. The accepance rate is $15.8 \%$ ! The problem is the plethora of manuscripts received continues and this is the reason that we have reduced the acceptance ratio from $23.0 \%$ in 2013 to $15.8 \%$ now and we will have to continue this reduction in the future.

As the official journal of SICOT we publish articles from more than 60 countries around the world including articles from authors in developing countries. This creates a challenging problem of balance between the interests of our members, the authors, our readers and the maintainance of a high Impact Factor for the journal.

The time from receipt of an article to acceptance/rejection is about three weeks and from acceptance to publication ONLINE FIRST about one month; then to appearence in the printed journal issue, a futher three months.

In 2006 we introduced special issues of the Journal, where one member of our editorial team with an interest in a specialist branch of orthopaedics is invited to assemble a selection of articles from experts around the world. Since 2013 we have published two special issues per year, in the February and September Issues. In February 2014, we published "Knee Arthroplasty" (Guest editor: Francesco Falez) and in September "Tissue Engineering and Regenerative Orthopaedics [TERO] (Guest editors: Marko Pecina and Slobodan Vukicevic). Issue number 2, to be published in February 2015, will address the subject of the "Shoulder" edited by Marius M. Scarlat, who will also be the new Editor-in-Chief of International Orthopaedics, following his appointment in the New Year 2015. We intend to continue this special issue endeavour, which we believe, broadens the appeal of our Journal.

Over the last three years, the names of all the reviewers have been published in the February Issue (No2) entitled: "Acknowledgement to Referees" but at the end of my mandate I would like once again to say: "Thanks a lot, dear colleagues for your support to our Journal". 
During my two editor's mandates there have been very great changes in the publication of our journal, however with the full co-operation of Springer, our publishers, we have managed to solve all the publishing problems and my thanks go to the Springer staff at all levels of responsibility.

Finally I would like, once again, to thank all members of the Editorial Board and the members of Executive Committee and International Council of SICOT for their assistance and support during last six years and I am happy to welcome our new Editor-in-Chief Marius M. Scarlat with the words written at the beginning of this Editorial.
A policy of constant development is essential in the world of modern, international, scientific publication and the Editorial team at International Orthopaedics will continue in their efforts to keep us in the forefront of this endeavour. These goals can only be achieved by mutual co-operation and the intention of this editorial is to stimulate all of us, both on the Editorial Board and in SICOT, to paricipate in this project.

Once again, I hope that we will receive sufficient good or high quality articles to obtain a ranking among the first ten orthopaedic journals.

Dear Marius I did my best ... and now it is up to you to realise our wishes. 